\title{
Review of Foreign Language Anxiety Relationship with Language Achievement of EFL Students in Saudi Arabia
}

\author{
Abdulrahman Akram Alsaleem ${ }^{1}$ \\ ${ }^{1}$ Department of English, College of Science and Human Studies at Hotat Sudair, Majmaah University, \\ Al-Majmaah, 11952, Saudi Arabia. \\ Correspondence: Abdulrahman Akram Alsaleem Department of English, College of Science and Human Studies \\ at Hotat Sudair, Majmaah University, Al-Majmaah, 11952, Saudi Arabia. E-mail: 371101596@s.mu.edu.sa
}

Received: November 14, 2019 Accepted: December 10, 2019 Online Published: December 28, 2019

doi:10.5539/ijel.v10n1p305 URL: https://doi.org/10.5539/ijel.v10n1p305

\begin{abstract}
This study is conducted to evaluate learning and teaching English as a foreign language (EFL) in the Kingdom of Saudi Arabia (KSA) since English is still treated as a foreign language. Despite the prevailing high-level anxiety in Saudi learners of the English language, there are limited researches available to study the impact of language anxiety on the achievement of the student in a particular language. This literature search study explored the underlying causes and impacts of foreign language anxiety (FLA) and then studied these impacts on the language achievement of Saudi students in EFL classrooms in KSA. Credible academic researches and conference papers are critically reviewed in the context of the relationship between foreign language anxiety and language achievement of EFL students in Saudi Arabia. The findings of the review revealed that government initiatives and exposure to globalization in Saudi Arabia, students are encouraged to get expertise in English through EFL courses. However, the review of literature demonstrated that Saudi students experience anxiety while learning English as an unknown language. Additionally, the level of understanding in students of FLA negatively affected their accomplishment. Therefore, the collaborative strategies in classrooms are needed with complete participation of language instructors and favourable environment with positive competition building strategies encourage EFL students to enhance learning.
\end{abstract}

Keywords: language anxiety, foreign language anxiety (FLA), learning, language achievement, Saudi Arabia, English as foreign language (EFL)

\section{Introduction}

Learning a foreign language and achieving proficiency has always been a challenge for native communities in the Middle East region. However, the infusion of global culture due to industrial developments and high influence of western corporations in the region increased emphasis on learning "English as a foreign language (EFL)". On the other hand, Aljafen's (2013) study concluded that learning and teaching EFL in the Kingdom of Saudi Arabia (KSA) is on a limited scale since English is still treated as a "foreign language in KSA". In the wake of recent reforms in the educating system of KSA, the facilitation to the learning and teaching of English are provided. However, the level of proficiency in the majority of EFL learners in KSA is still very low. Thus, the level of competence is low in English that shows the increased anxiety feelings in the EFL learners quite obvious in the EFL classes in the kingdom. As a result of anxiety, participating in EFL learning in the class decreased and they become reluctant to participate in presentations and class discussions. The other symbols of anxiety are the unwillingness to speak or reluctance in giving answers, never or seldom asking questions, and overly depending on the teachers' help in doing the class and in assignments (Alrabai, 2014; Al-Asmari, 2015). As a collectivist society, the academic culture of KSA also played a significant role in heightening anxiety levels in EFL courses. The reluctance of students also resulted in the domination of EFL teachers in making students follow the; learning strategies such as memorization, reception, and reproduction, and most students act as passive observers in the EFL classes. The non-participative practice leads to the uneasiness feeling that negatively affects the students learning and their grades in EFL courses (Javid, 2014).

Because of the prevailing high-level anxiety in Saudi learners of the English language, there are limited researches available on the impact of language anxiety on the achievement of the student in a particular language. Though the level of conducting researches in EL learners in KSA is quite high mostly studies are focused on the 
causes in the anxiety and the performance of students in EFL classes. Therefore, there is a need for comprehensive research to undertake the language anxiety critical and evaluate the impact on the language achievement of students in EFL classes. The limited researches are available on foreign language anxiety (FLA) and the achievement of foreign language (AFL) in Saudi Arabia students.

Thus, a high need for research on the relationship between FLA and AFL is found and is extended outcomes concerning the specific context of KSA students. This research paper aimed at investigating this phenomenon to a large extent to explore the underlying causes and impacts FLA and then recommend to overcome the extensive levels of language anxiety in EL classes. The potential outcomes of his research will assist students and teachers in KSA to handle the devastating feeling of anxiety and to increase the rate of achievement in foreign language expertise.

\subsection{Research Questions}

1) What are the causes and significant factors affecting the level of FLA among Saudi EFL students?

2) How is the level of FLA related to language achievement in Saudi Arabia for increasing English language achievement among EFL learners?

\subsection{Method}

This secondary research comprises on collection of relevant literature on foreign language anxiety and its prevalence in students to English as a foreign language (EFL). The key words of FLA an AFL were basic in tis literature search, specifically for students in Saudi Arabia (KSA). Hence, the inclusion criteria of the literature was to cover the issues of FLA and EFL for students if KSA in period of 2010 till 2018. The collected literature from academic journals databases such as EBSCO, Science Direct, Emerald, and Springer Linker. The collected articles were synthesised, classified, and then discussed in detail. After first phase, more articles were searched for relevant content. In the end about 27 articles were found more reteam and connect do the topic. A thematic literature review techno was found suitable for the qualitative findings from literature. The discussion of theoretical background literature was not confined in the assigned period of search as old theories are also included in discussion.

\section{Theoretical Framework}

\subsection{Foreign Language Anxiety}

Language Anxiety is termed as the individual differences present during the language learning that can lead to the feelings of discomfort and restlessness in students. The personality theories considered anxiety as the ore element in describing human feelings and actions (Al-Shboul, Ahmad, Nordin, \& Rahman, 2013). In the wide perspective of anxiety, Dörnyei (2005) describe it as a sensation state related to the unclear condition of fear, discomfort, nervousness, and uneasiness that are not seemed to have a specific reason or explanation. Moreover, in previous resources such as that of Young (1992), anxiety became the center of attention in the evaluation of 'students' issues during EFL sessions. Further Young (1992) treated the concept of foreign language anxiety (FLA) in terms of a complex psychological phenomenon associated with the learning of non-native languages. According to MacIntyre and Gardner (1994), FLA represents the tension and apprehension feelings in the context of the learning involved second and third languages in collective and traditional societies. The aspects of speaking, learning and listening, and the emotional reactions evolved in the processing of second and third languages information are important in literature. Another important definition of FLA is given by MacIntyre (1999) as "the worry and negative emotional reaction aroused when learning or using a second language" (p. 27). However, the earlier explanation of Spielberger (1983) argued the later definition of FLA as a "subjective feeling of tension, apprehension, nervousness, and worry associated with an arousal of [the] autonomic nervous system" (p. 15).

\subsection{Foreign Language Anxiety Components}

Several causes of foreign language anxiety (FLA) have been identified in many studies. The anxiety provoked in diverse situations depends on the mood, surrounding factors, and other elements in the language classroom. Based on the above-described definitions of the FLA, Horwitz et al. (1986) suggested three distinct components of classroom anxiety. These components are test anxiety communication apprehension, and negative assessment fear. The apprehension of communication involves the fear of speaking in class, lack of effective listening, and absence of comprehension of the class activities involve FL. As per the explanation of Cubukcu (2007), communication apprehension illustrates the shyness resulted from the anxiety of fear of communication with others. Moreover, the term test anxiety resulted from the fear and apprehension of exam failure, poor test performance, and failure to fulfil high expectations of self and others. The unrealistic performance outcomes for 
students are either expected by students or their teachers or parents. Lastly, the third component of negative evaluation fear is the result of failure to evaluate from teachers and other people in surroundings such as colleagues, bosses, relatives, and others. In this regard, Lucas, Miraflores, and Go (2011) suggested that negative evaluation anxiety leads to the avoidance of evaluative sessions in students such as bunking classrooms of foreign language. Moreover, the additional pressure to achieve the performance of extra internal fear and anxiety element in all three components. Moreover, in another research of Young (1991), FLCA attribute to six components of 1) personal and interpersonal anxieties; 2) language learning beliefs of learners; 3) instructor beliefs; 4) interactions of instructor and learner, 5) procedures in classrooms; and 6) testing procedures in language learning. Besides, Horwitz (2001) contributes through the addition of perceived teacher resistance as the main actor in increasing anxiety. It is also noted that the other sources of anxiety in the classroom raised from a value in effective speaking, negative learning experiences, the incapacity of comprehensions, and other physical and psychological sources in language classes.

\subsection{Types of Foreign Language Anxiety}

There are several ways to categorize foreign language anxiety (FLA) in classrooms and other public places. The classification of Scovel (1978) mentioned two broad categories as facilitating anxiety or debilitating anxiety. The positive type of Facilitating anxiety proved advantageous and referred to the moderate anxiety levels when FL learners are exposed to challenges or difficult tasks. This anxiety generates adrenaline in the body that results in positive impacts on language learning since the brain supports extra effort to solve challenging tasks (Mills et al., 2006). In contrast, debilitating anxiety condition occurs when high levels of anxiety prevail. This excessive anxiety resulted in negative outcomes such as work avoidance, which leads to negative effects such as avoidance of work, lower performance, and frustration. In general, most previous studies have shown that FLA has a devastating effect on foreign language learning (Gregersen, 2005; Casado \& Dereshiswsky, 2004). Horwitz et al. (1986) also differentiate this form of anxiety from general anxiety and referred to it as Foreign Language Classroom Anxiety (FLCA), which can be considered as situational anxiety in the context of the FL classroom. According to Abu Rabia (2004), the language learner experiences anxiety that is reflected in forms of worrisome attitudes, physical insecurity, and inability to increase engagement in any situation pf learning.

Given the other studies of Ellis (1994) and Horwitz et al. (1986), there are three broad classes of anxiety concerning its occurrence.

1) Trait Anxiety: This type is due to the inherent capabilities or personality traits to become uneasy in challenging situations. The persons facing this type are also predisposed to anxiety in their normal lives as well (Ellis, 1994).

2) Situational anxiety: According to Ellis (1994), if the person feels anxiety about any particular situation or in any event then it is termed a situational category. For instance, high-intensity of society is reflected during class presentation and class discussions in language classrooms. Thus, people who face the fear of public speaking are attributed to this type of anxiety.

3) State anxiety: there are particular states in which anxiety becomes prevalent and visible (Ellis, 1994).

Thus, the above classification shows that FLCA falls in the category of situational anxiety as compared to others since it occurs in specific classroom situations of FL learning.

\section{Discussion on Findings}

\subsection{FLA and Language Achievement}

The recent researches on FLA in the current era are involved in the investigation of the underlying causes and consequence of FLA and its relationship with the performance and achievement in language learning. The success of learning foreign languages largely based on various contexts. According to the findings of the researches conducted by Demirdaş and Bozdoğan (2013) and Wang (2011), there is a negative consistent and strong relationship between language achievement and FLA. The findings in the study of Geotz and Hall (2013) showed that the correlation between language achievement and anxiety lies in the range of -0.20 to -0.25 . Similarly, using English as an FL in non-native students' context, the study of Wilson (2006) provided a measurement if the FLA in Spanish students EFL courses. In this study, Wilson (2006) found the correlation of oral language speaking skills with FLA as -0.49 , which is negative, but strong and significant and shows a considerable impact. Moreover, in another research on EFL students in China and the impact of FLA n he language learning success is conducted in studies of Lu and Liu (2011) and Zheng (2010). The results of these studies conclude significant relationship presence between FLA and success of language achievement in Chinese students. In another example on a sample of Turkish students, Batumlu and Erden (2007) concluded that there is 
an important and inverse relationship that exists between language achievement and FLA, the correlation coefficient calculated in the study of Batumlu and Erden (2007) was -0.45 . Hence a large body of literature found on the relationship of FLA and language achievement in FL students of multiple ethnicities. However, am, there is a dearth of literature on the Saudi EFL students in the international literature on language achievement.

In context of KSA students, among the limited studies found on the relationship pf students' performance and the foreign language communicating anxiety scale (FLCAS), the important ones are of Alrabai (2014), Aljafen (2013), Asif (2014), Javid (2014), and Al-Asmari (2015) and of Hamouda (2012). These studies considered the performance measure of student in EFL as the resultant grades and FLA was measured with the help of FLCAS. The findings of these scarce researches showed a wide variation in the resultant correlations. There were there conflicts found as well in these studies such that the variable communication apprehension found significant $\mathrm{n}$ measuring FLA in Saudi students. However, in nearly all studies one prevalent trend of increasing output academic performance of Saudi students in EFL courses with the share decrease in the level of FLA.

Tao's negative and significant correlation in FLA and language achievement of Saudi students showed a nearly similar trend to that of Turkish, Chinese, Spanish, and other non-native speaker's researches. Moreover, the studies of Zhang et al. (2010) and the results of the analysis indicated that language anxiety in foreign language learning is largely affected by the negative evaluation fear. The fear or evaluation by teachers and fellow student become an important source of anxiety in EFL courses. Similarly, the other variable o anxiety that affects language achievement is the accuracy and speed of learning in students. The individual preferences of perceptions. Knowledge level and learning abilities in students contribute toward the level of class scores and learning abilities in EFL programs. According to Liu and Chen (2013), the quality of communication is highly affected by the High levels of anxiety since the information is not sharply retrieved due to interruption of blank moment or freezing up moments. In some cases, the increase in anxiety negatively affects the speaking power of normal students. Consequently, based on individual experiences, Arnaiz and Guillén (2012) argued that language learning can be an unpleasant and disturbing experience and led to the decline in Self-perceived proficiency in foreign languages. Similarly, high proficiency perception of students in HFL resulted in low FLA levels as compared to the students who perceived themselves as less capable and less competent. Thus, the researches discussed above provide evidence that there are many causes behind the increases in FLA and the relationship is significant with the language performance of students ibn EFL courses. The other foreign languages such as French, Spanish, and Arabic are s discussed in the literature but their discussions are out of scope since this paper is specifically dealing with the impact of FLA on the proficiency of Saudi Arabian students in EFL class. Therefore, there is a limit to the discussion of their foreign languages found in this section.

\subsection{The Significance of English Learning in KSA}

Nib lock, (2006) concluded in the study that English was introduced as a foreign language in the Saudi Arabian educational system at the end of the 1920s. During the early decades, the foreign language students faced difficulties due to difference from spoken Arabic, however, soon realized its international communication importance and then English become one of the prominent foreign languages for Saudi Arabian natives and society alike. Moreover, the discovery of oil reserves had increased proliferation of multinational companies in the post-World War II period, increased the communication importance of EFL further. According to Al-Saraj (2014), the opportunities in foreign multinationals and international careers have increased pressures on Saudi students to learn English. The increase in industrialization and start off avourable relationships with America and the European nations further signify the importance of understanding and speaking English. Similarly, Faruk (2013) concluded that Saudi students have not considered the importance of English in their careers for many decades and taken this prevailing global trend for granted. The research indicated the other use of foreign languages in career advancement, nation strengthening, and spreading of the religion of native population foreign countries. Hence, English understanding and fluent in speaking are not only limited to the business concerns but the prevalence of the latest trend in socio-cultural and economic and socio-political environments are important domains for both local and global levels.

Given the economic prosperity of the region, Mahboob and Elyas (2014) study suggested that the significance of English in the education system of KSA is meant for its perceived importance in international economics infrastructures. The language of international trade is declared as English by ventures, therefore, the business and career professionals in Middle East regions are also affected by this global wave.

Moreover, the English teaching at school levels is found at all public and private school systems. The language is also used widely in management and business operations, business communication, training and development of employees. The major companies, government departments, and international organizations are communicated 
in English and use it widely in inbound and outbound communications. According to Alrashidi and Phan (2015), the presence of more than 10 million expatriates in Saudi Arabia make the communication in English evident for native Saudis as well. Therefore, the classes in EFL and short language courses are very popular with students of KSA schools and colleges. Thus, the use of English fluency is basic selection eligibility of candidates in high profile private and public sector jobs. The other benefits of English as a mode of official communication enable the KSA government to invite foreign professionals and foreign investment in the country.

In the advent of modern technological changes, Bashehab and Buddhapriya (2013) emphasized that the support of a knowledge-based economy is widely accepted if the proficiency in English is unquestionable. The country can support human resource development and skills-building through expertise in foreign languages. Also, a means to resolve the issues generated due to the high dependence of ever depleted oil reserves. In this concern, the heavy investment of the KSA government in recent years on education and professional skills development is commendable. In another study of Dewaele and Al Saraj (2015), the important predictor of anxiety is found as self-efficacy in Arab origin students of EFL. Participants from different Arab regions who were found an expert in oral communication in English face less anxiety in EFL classes. Moreover, the government-subsidized EFL programs offer full scholarships that reduce the FLA levels for English language programs (Javid \& Umer, 2014). However, self-perceived measures of competence are found less valid in Dewaele and Al Saraj (2015) study and raised concerns for future research needs.

Given the education reforms and subsidized EFL programs, the tendency of Saudis for education in overseas locations also increased. For example, Taylor and Albasri (2014) research discussed that there is a dramatic increase in overseas Saudi Students in western universities. The figure of Saudi students reported before 2005 was around 5000 students that has remarkably increased to 100 thousand in 2013-2014 (Ismail, 2015). In other words, the economic prosperity in KSA, government reforms opened doors for western companies and the increase in iconic and social status of Saudi families lead to 100s of thousands of Saudis to study and live abroad. Apart from the political support pf English as an official language after Arabic, the social infrastructure of Saudi society has also largely affected. The latest trends of technological revolution, economic growth, national prosperity, and wake of freedom turned the Saudis students to have a borderless and limitless society. Additionally, Alrashidi and Phan's (2015) research considered that the access and advancements in communication to technologies allow Saudis Students to communicate with people from other societies.

\subsection{FLA and English Achievement in Saudi Arabia}

Despite the ever-increasing importance of EFL education and perception of youth towards English learning, there is a scarce research found in context of FLA and EFL achievement in KSA context (Ismail, 2015). Some investigations are found in recent years due to the importance of adequate researches in this domain. Therefore, the review of available researches is done to find some amazing and valuable information. In order to do that, the research of Al-Saraj (2013) conducted in KSA and utilized a multi-strategy approach that involved survey individuals and focus groups of ten female undergrads about their casual perceptions. This examination of students involved perception of language anxiety that pertains to the instructor-student relationships, class environment, and threats of negative assessment during the classes. The results revealed that presence of anxiety towards fear of negative assessment, teachers' communication barriers, and aggressiveness. In another research, Alrabai (2014a) led a test anxiety to investigate the impacts of the instructor's anxiety-decreasing techniques on students' FLA in the Saudi setting. He utilized FLCAS scores when a 10-week test treatment course to assess students' anxiety and study hall perceptions to evaluate the educator's anxiety-diminishing practices; Alrabai built up a positive causal connection between instructors' anxiety-decreasing practices and students' FLA in that anxiety-lessening techniques by instructors brought about low degrees of language anxiety in students.

Hardly any examinations have researched the effect of foreign language anxiety (FLA) among Saudi students in different settings (Alrabai, 2014; Aljafen, 2013). A large portion of discoveries of the investigations showed that FLA assumes a significant job in language learning in the Saudi setting. For example, Hamouda (2013) examined the reasons for Saudi students' reluctance to take an interest in the English language study hall. 159 students from Al-Qassim University took an interest in the investigation. His outcomes demonstrated an extensive number of students were hesitant to react to the educator and stayed quiet in oral English language study halls because of different causes, for example, low English capability, a fear of talking before others, negative assessment, modesty, absence of certainty and arrangement, and an anxiety of committing errors. Additionally, Asif (2014) upheld this case in an examination to investigate the components that reason language anxiety in Saudi EFL students, similar to the study of Javid (2014) on the expertise and issues facing by Saudi students in EFL classes. The findings from these researches demonstrated that FLA assumes a significant job in EFL learning for Saudi students. A large portion of the Saudi EFL students was found to have a dread of 
committing errors. They didn't step up to the podiums. They want to stay silent, dreading they would commit errors among companions. Thinking about different abilities, Aljafen (2013) analyzed the effect of composing anxiety among 296 EFL Saudi students in science universities. The members rounded out the English composition fear/frame of mind test (EWAT) scale overview. The discoveries of this examination demonstrated that the three gatherings (Engineering, Pharmacy and preliminary year) have nearly similar moderate sentiments of English composition anxiety. He uncovered a few reasons for composing anxiety among Saudi students: shortcoming of past English training, absence of trust recorded as a hard copy, and anxiety of negative assessment. Alrabai (2014) examined the degree of anxiety among 1,389 Saudi EFL college students and wellsprings of unknown dialect anxiety (FLA) through three years by utilizing the Foreign Language Classroom Anxiety Scale (FLCAS). Moreover, the discoveries of Alrabai's (2014a, 2014b, 2016) investigations indicated moderate to elevated levels of anxiety, with correspondence apprehension being the key reason for FLA.

The low English language skill of Saudi students is a multidimensional and complex wonder is also discussed in parallel studies on Iranian EFL students (Nahavandi, \& Mukundan, 2013) and for EFL students in Pakistan (Nazier et al., 2013). To address the serious issues and to look for down to arrangements, it is critical to initially address the variables fundamental to this issue. Similar to the findings of $\mathrm{Wu}$ (2010) and Shalbani (2012), low English language accomplishment can be ascribed to an assortment of interrelated elements running from student-related factors such as sexual orientation, inspiration, and anxiety as compared to the sociocultural factors included the society, culture, and religion. Moreover, the factors identified in the literature for EFL are educator conduct and practices (Shalbani, 2012), the educational program (Lu \& Liu, 2011; Lucas et al., 2011). However, the different elements identified with issues with the educational system in Saudi Arabia such as stuffed classes, an absence of the prepared instructor, and innovation absence may likewise add to the poor EFL results (Moskovsky et al., 2015). Similarly, Mohammed (2015) conducted long research on student singular factors that demonstrates that low accomplishment in the unknown dialect learning is the consequence of a mind-boggling connection of both inner and outer variables for Saudi EFL students. For instance, Mohammed (2015) discussed the impact of a controlling, forceful instructor as an outside factor that adversely influences students' inspirations, while the anxiety that such educators indoctrinate in their students is an inside factor that contrarily influences these students learning results in EFL courses.

\section{Conclusion}

In the wake of looking into the writing, there is a requirement for more research on FLA furthermore, its relationship to English accomplishment in the Saudi setting. Therefore, this investigation was intended to look at the connection between FLA and students' English accomplishments in Saudi Arabia. There has been lacking exploration of the connection among FLA and unknown dialect accomplishment in the Saudi EFL setting. Along these lines, the basic role of this examination was to look at the impact of FLA on the English capability of Saudi college students studying English. This review is one of only a handful couple of qualitative literature review-based examinations that exhibited the relationship between FLA and foreign language accomplishment in this populace. The discoveries demonstrated that Saudi college students experience anxiety while learning English as an unknown dialect. Also, the students' degrees of FLA negatively affected their accomplishment. Concerning sexual orientation, there was no noteworthy distinction among guys and females' degrees of FLA. The discoveries of this investigation will profit English instructors, teachers, specialists, and students themselves. Those who are associated with learning and encouraging unknown dialect ought to participate to limit the impacts of FLA and make welcoming learning conditions that will improve the students' exhibition in learning unknown dialects.

\subsection{Recommendations}

Based on the above discussion and findings of this research following recommendations are made:

1) Open communication of learners with the faculty and teaching instructors is very important to convey the actual problems and issues facing daring the EFL courses. Other student colleagues and family members can also consult to share the anxiety feelings since communication and allows alleviating anxiety feelings. The training of English teachers in school and EFL sessions need pre-service and during service, training handles the anxiety issues of students. The sources and consequences of anxiety and the strategies to overcome these anxiety symptoms are important or teachers to understand. EFL policies in Saudi schools and colleges include teachers' training and student counselling sessions. Teachers' training will also be useful to increase the awareness levels of teachers about the severity of FLA and to enable these teachers to handle the symptoms of FLA during their classes/sessions.

2) Overcrowded classrooms are another reason for lack of communication and fear of evaluation in EFL classes. 
Students feel discomfort in sharing views and answering questions due to the apprehensions of teachers, scolding, and humiliation in public. Facing a large number of audiences is also difficult during class discussion and presentations, therefore small groups and interactive class sessions are required to increase the effectiveness of EFL programs, the planning of EFL classes should be separate from the autonomous and crowded learning spaces in Saudi Arabia schools and other public institutions. Thus, induction of more EFL teachers and the arrangement of more classrooms with Audio-visual facilities will add value to the existing EFL programs.

3) More research on the further issues of EFL programs is needed, despite the findings of the current research, more research is needed to understand the perceptions of students and problems facing by instructions in Saudi education systems. More experimental studies, use of FCLAS in testing the FLA at different levels of students, and random sample testing during the regular sessions are some controlling and monitoring strategies. These monitoring techniques will assist in understanding the barriers to attain the desired level of language achievement.

4) The learning environment contributes to a large extent in decreasing anxiety levels, an open, informal, friendly, and relaxing class environment is the responsibility of teachers to establish in EFL sessions. Students can feel much are ease and become open to discuss issues and problems with the teachers and fellow students. Moreover, environmental cooperation and collaboration are needed in these classrooms as compared to the used technique of competition among students. The competition can hinder the performance of those students who are shy and cannot discuss openly. Therefore, interactive activities, gaming, exercise, other class activities such as role-plays, storytelling, and making presentations are recommended to control the FLA in students. The beginning of lectures in classes should not be started with quizzes, lessons that encourage frustrations in students, and compelling activities. The beginning of class is suggested to be lively, simple, and comprise $f$ easy to follow exercises and new concepts to learn in FL. The use of videos and other multimedia presentation can assist teachers to make use of audio-visual abilities of students and enhance their understanding of EFL.

5) Working in project teams and small groups with fairly moderate challenging tasks can be used to modify the language problems. The use of word games, puzzles, and pair-based work, and simulations of games and activities are some interactive modes of teaching in small groups. The increase in students' vocabulary and expertise in using new words in sentences can help Saudi students to overcome weak vocabulary and less command on grammar and structure.

6) The simple and standardized mode of testing and exams are needed in EFL but consideration of the diverse levels of expertise and understanding differences in students if the same class need an empathetic behavior of teachers. Ignoring small mistakes of students and encouragement to rectify their mistakes can keep the student to control their level of anxiety. The examination and testing system should also breed me an informal and friendly atmosphere so the test anxiety and situational anxiety factors should be under control. The language achievement is highly correlated with the level of FLA, therefore, consideration of individual shyness verbal abilities and attitude towards learning should also give proper weight in a decision related to the learning achievement. The use of specific learning techniques such as techniques to overcome difficulties in comprehension understanding and strategies to build effective vocabulary are some important stages in language achievement.

\subsection{Future Research Implications}

Given the theoretical exploration of the current research, future researches can use this literature-based result as the foundation of further investigation. The inclusion of other variables in the model of FLA and language achievement relationship as moderators and mediators can extend the implications of this research. Moreover, the use of an explanatory study with the use of a large sample survey of Saudi students and detailed interviews of English language faculty in schools can add triangulation in the findings of future searches. Additionally, the model o FLA relationship with language achievement can be extended in the long term by using longitudinal study. The long-term studies can investigate the impact of FLA on student learning abilities of an FL in the long term. The samples of different age group students and their learning achievement concerning the prevailing FLA can also be done in future researches.

The limitations of the research are related to the use of only secondary data from the credible research journals the exploratory research does not include and other qualitative findings from interviews, focus groups, and any other form of primary data. Therefore, future researches can use a mix of qualitative and quantitative data and primary data along with the secondary data. Finally, the research was only concerned with the causes and implications of FLA and its impact on the relationship with language achievement. A further investigation of more detailed factors and other environmental concerns can help to judge the language achievement of Saudi students in EFL. 


\section{Acknowledgement}

The author would like to thank Deanship of Scientific Research at Majmaah University for supporting this work.

\section{References}

Aljafen, B. S. (2013). Writing anxiety among EFL Saudi students in science colleges and department at a Saudi University. Unpublished master's thesis, Indiana University of Pennsylvania, Indiana, PA.

Al-Khairy, M. H. (2013). English as a foreign language learning demotivational factors as perceived by Saudi undergraduates. European Scientific Journal, 9, 365-382.

Alrabai, F. (2014). A model of foreign language anxiety in the Saudi EFL context. English Language Teaching, 7(7), 82-101. https://doi.org/10.5539/elt.v7n7p82

Alrabai, F. (2016). Factors underlying low achievement of Saudi EFL learners. International Journal of English Linguistics, 6(3), 21-37. https://doi.org/10.5539/ijel.v6n3p21

Alshahrani, M., \& Alshahrani, A. (2015). An investigation of anxiety among elementary school students towards foreign language learning. Studies in Literature and Language, 11(1), 29-40.

Al-Shboul, M. M., Ahmad, I. S., Nordin, M. S., \&Rahman, Z. A. (2013). Foreign language anxiety and achievement: Systematic review. International Journal of English Linguistics, 3(2), 32-45. https://doi.org/10.5539/ijel.v3n2p32

Alrabai, F. (2014a). The influence of teachers' anxiety-reducing strategies on learners' foreign language anxiety. Innovation in Language Learning and Teaching, 8(1). https://doi.org/10.1080/17501229.2014.890203

Alrabai, F. (2014b). Reducing language anxiety \& promoting learner motivation: A practical guide for teachers of English as a foreign language. Raleigh, N.C.: Lulu publishing company.

Alrasheed, S. (2012). Exploring the nature of the Saudi English teachers' beliefs and attitudes towards EFL and its effects on their teaching practice. Paper presented at the Saudi Scientific International Conference, London, England.

Al-Saraj, T. M. (2013). Foreign language anxiety in female Arabs learning English: Case studies. Innovation in Language Learning and Teaching, 257-278. https://doi.org/10.1080/17501229.2013.837911

Alzayid, A. (2012). The role of motivation in the L2 acquisition of English by Saudi students: A dynamic perspective (Unpublished master's thesis). Southern Illinois University Carbondale, IL.

Atasheneh, N., \& Izadi, A. (2012). The role of teachers in reducing-increasing listening comprehension test anxiety: A case of Iranian EFL learners. English Language Teaching, 5, 178-187. https://doi.org/10.5539/elt.v5n3p178

Awan, R., Azher, M., Anwar, M. N., \& Naz, A. (2010). An investigation of foreign language classroom anxiety and its relationship with students' achievement. Journal of College Teaching and Learning, 7(11), 33-40. https://doi.org/10.19030/tlc.v7i11.249

Aydin, S. (2008). An investigation on the language anxiety and fear of negative evaluation among Turkish EFL learners. Asian EFL Journal, 31, 421-444.

Aydin, S. (2009). Test anxiety among foreign language learners: A review of literature. Journal of Language and Linguistic Studies, 5, 127-137.

Demirdaş, Ö., \& Bozdoğan, D. (2013). Foreign language anxiety and performance of language learners in preparatory classes. Turkish Journal of Education, 2(3), 4-13.

Dewaele, J.-M., \& Al Saraj, T. (2015). Foreign Language Classroom Anxiety of Arab learners of English: The effect of personality, linguistic and sociobiographical variables. Studies in Second Language Learning and Teaching, 5(2), 205-230. https://doi.org/10.14746/ssllt.2015.5.2.2

Faruk, S. (2013). English language teaching in Saudi Arabia: A world system perspective. Scientific Bulletin of the Politehnica University of Timişoara Transactions on Modern Languages, 12(1), 73-80.

Faruk, S. (2014). Saudis' attitude towards English: trend and rationale. Professional Communication and Translation Studies, 7, 173-180.

Geotz, T., \& Hall, N. (2013). Emotion and achievement in the classroom. In J. Hattie \& E. M. Anderman (Eds.), International guide to student achievement (pp. 192-195). New York, NY: Routledge.

Hagler, A. (2014). A study of attitudes toward western culture among Saudi university students. Learning and 
Teaching in Higher Education: Gulf Perspectives, 11(1), 1-14.

Hamouda, A. (2013). An exploration of causes of Saudi students' reluctance to participate in the English language classroom. International Journal of English Language Education, 1(1), 17-34. https://doi.org/10.5296/ijele.v1i1.2652

Hashemi, M., \& Abbasi, M. (2013). The role of the teacher in alleviating anxiety in language classes. International Research Journal of Applied and Basic Sciences, 4(3), 640-646.

Huang, J. (2012). Overcoming foreign language classroom anxiety. New York, NY: Nova Science Publishers, Inc.

Ismail, N. M. (2015). EFL Saudi Students' Class Emotions and Their Contributions to Their English Achievement at Taif University. International Journal of Psychological Studies, 7(4), 19-42. https://doi.org/10.5539/ijps.v7n4p19

Javid, C. Z. (2014). Measuring Language Anxiety in an EFL Context. Journal of Education and Practice, 5(25), 180-192.

Javid, C., \& Umer, M. (2014). Saudi EFL learners' writing problems: a move towards solution (pp. 4-5). Proceedings from GSE 2014: The Global Summit on Education.

Kao, P. C., \& Craigie, P. (2010). Foreign language anxiety and English achievement in Taiwanese undergraduate English-major students: An empirical study. Hungkuang Journal, 61, 49-62.

Khan, I. (2011). Learning difficulties in English: Diagnosis and pedagogy in Saudi Arabia. Educational Research, 2(7), 1248-1257

Liu, M., \& Huang, W. (2011). An exploration of foreign language anxiety and English learning motivation. Education Research International, 2011. https://doi.org/10.1155/2011/493167

Lu, Z., \& Liu, M. (2011). Foreign language anxiety and strategy use: A study with Chinese undergraduate EFL learners. Journal of Language Teaching and Research, 2(6), 1298-1305. https://doi.org/10.4304/jltr.2.6.1298-1305

Lucas, R. I., Miraflores, E., \& Go, D. (2011). English language learning anxiety among foreign language learners in the Philippines. Philippine ESL Journal, 7, 94-119.

MacIntyre, P. D., \& Gregersen, T. (2012). Affect: The role of language anxiety and other emotions in language learning. In S. Mercer, S. Ryan \& M. Williams (Eds.), Psychology for language learning (pp. 103-116). New York, NY: Palgrave Macmillan. https://doi.org/10.1057/9781137032829_8

Mahboob, A., \& Elyas, T. (2014). English in the Kingdom of Saudi Arabia. World Englishes, 33, 128-142. https://doi.org/10.1111/weng.12073

Mohammed, A. (2015). EFL effective factors: Anxiety and motivation and their effect on Saudi College student's achievement. Arab World English Journal, 6, 201-218. https://doi.org/10.24093/awej/vol6no2.16

Moskovsky, C., Alshahrani, M., Ratcheva, S., \& Paolini, S. (2015). Aptitude as a predictor of second language achievement: an investigation in the Saudi Arabian context. Arab World English Journal, 6, 3-21. https://doi.org/10.24093/awej/vol6no1.1

Nahavandi, N., \& Mukundan, J. (2013). Foreign language learning anxiety among Iranian EFL learners along gender and different proficiency levels. Language in India, 13, 1.

Nazir, M., Bashir, S., \& Raja, Z. (2014). A study of second language speaking-anxiety among ESL intermediate Pakistani learners. International Journal of English and Education, 3, 216-229.

Shabani, M. B. (2012). Levels and sources of language anxiety and fear of negative evaluation among Iranian EFL learners. Theory and Practice in Language Studies, 2, 2378-2383. https://doi.org/10.4304/tpls.2.11.2378-2383

$\mathrm{Wu}, \mathrm{K} . \mathrm{H}$. (2010). The relationship between language learners' anxiety and learning strategy in the CLT classrooms. International Education Studies, 3, 174-191. https://doi.org/10.5539/ies.v3n1p174

\section{Copyrights}

Copyright for this article is retained by the author, with first publication rights granted to the journal.

This is an open-access article distributed under the terms and conditions of the Creative Commons Attribution license (http://creativecommons.org/licenses/by/4.0/). 